\title{
The development of community-based tourism business in Phu Khratae Island, Nonklang Sub-district, Phiboonmangsaharn District, Ubonratchathani Province, Thailand
}

\author{
P. Somnuek \\ Tourism Department, Faculty of Liberal Arts, \\ Ubon Ratchathani University, Thailand
}

\begin{abstract}
This developmental research was aimed to: 1) study the potential of the community for developing tourism business, 2) investigate and compare the levels of satisfaction of tourists towards the services and 3) analyze the effects of the implementation of tourism activities. The participatory action research was used for this study and data collection was done through questionnaires, which were later analyzed by using the summarization together with descriptive and inferential statistical measurements. Respondents in this study consisted of representatives of the community and senior members, committee of the community tourism association, and tourists. Research findings were as follow:

1) The tourist location of the community was found to have the potential for being a new eco-tourism location and the committee of the tourism club were found to have the potential to manage the community tourism business.

2) During the first phase of appraisal, tourists were found to have dissatisfaction with the overall service, but after a progressive evaluation, tourists were found to have higher satisfaction.

3) The local community members also stated that the various tourism activities produced positive socio-economic, cultural, lifestyle and environmental effects.

Keywords: business development, tourism business, community-based tourism.
\end{abstract}




\section{Introduction}

An interview was conducted with Mr. Padungsak Seesang, the president of the Sub-District Administrative Office of Nonklang, Phiboonmangsaharn district, Ubonratchathani province [1]. This interview showed that Phu Kratae Island is situated in an area shared by Ban-Dome-Pradid, Ban-Nong-Makluea, and BanNonklang communities of Nonklang sub-district, Phiboonmangsaharn district, Ubonratchathani province. It is an island of about 625 acres surrounded by water but above the reach of year-round flood. The reason it is called Phu Kratare is that when the villagers look up at it from below, it is seen as a highland which the Isaan people call "phu", and on this highland live a large quantity of krataes, which are the same kind of animal as the squirrel. Thus, the island is continually called "Phu Kratae". The water that surrounds Phu Kratae Island comes from the Sirinthorn dam constructed in 1968. Mueang Dome village, which was situated near Phu Kratae, became submerged in the water along with farmland of about 12,500 acres. The geography of Phu Kratae Island is a mixture of stony mountain and mixed forest consisting of plants such as Parinari anamense Hance, Lythaceae, Sharea obtusa, Burmese sal, loosestrife, Afzelia and a variety of herbal plants, for example, bitterbush and wild forest noni. It is an inland amid the water rich with natural resources, timber and biodiversity. Therefore the people guard the island dearly by prohibiting anyone from living on the island or clearing the land, but preserving it and earning a living from it by gathering mushrooms, vegetables, as well as native food, such as red ant eggs around the area.

The landscape of Phu Kratae is beautiful. It is considered a prominent topography amid the water that is peaceful and relaxing due to its small size during the season of the flood. During the dry season when the water has gone, you can travel over ground to reach it, and during the rainy season you can reach the island via one of the boats or fishing rafts from the neighbouring villagers. On Phu Kratae Island there is an area for playing in the water at the sandbank in the northern and southern parts; the eastern part is suitable for students and tourists to camp. The middle part of Phu Kratae provides a convenient parking area for tourists and the western part, which is regarded as the back entrance to Phu Kratae, currently has the Phu Kratae Dharma Taram abbey where only one monk is staying. Moreover, the area around Phu Kratae Island can be developed into a nature trail for studying natural herbs, and the square can be made into a natural classroom for students and tourists to study living in the forest. There are also natural reeves around the southern part of the island all the way through to the eastern part. One can relax while enjoying the scenery of the island and sharing a meal together. All around the four sides of Phu Kratae Island are the villagers' square dip nets equipped with lights for catching anchovy on moonless nights. Tourists started coming from nearby regions to Phu Kratae to relax and enjoy the water during Songkran in 2006, so around 10 villagers from Nonklang district opened restaurants selling food and drinks to tourists with the average income of about 10,000 baht per capita throughout the season. Moreover, 500 
boy scout and girl scout students from other districts were sent to camp in Phu Kratae Island around the same time.

For the above reasons, plus the interest in developing a new tourist location in this region, there has been cooperation with community leaders in surveying the area and collecting basic data of the community to use in making primary decisions regarding the conduct of a research on community-based tourism by considering rewarding management of the community members, tourists' opportunity to study along with the community, traditional way of living and capability of administration under factors of ecological tourism. Hopefully there will be a new tourism location in the area with a large number of visiting tourists, which means earning income for the area and promoting the long-term participation of the community members in administrating tourism.

\section{Research objectives}

This research for tourism development is done by examining the potential of the community to develop tourism business; examining and comparing the satisfaction of tourists with services and analyzing the results from tourismrelated activity operation.

\section{Literature review}

All related theories needed to be examined to be used as a theoretical framework of the research are sustainable development [2], Phenomenology[3; 4] and mechanism of social change [5].

As seen from this theoretical framework, the major concept which is the objective of this research for development is community of sustainable development. The survey of all the literature on social works yields that for sustainable development, a community has to function on the basis of selfsufficiency in every aspect and direct the progress of its society towards the social community ideology. Thus, this is a major vision towards which a community should aim in the process of its societal development. Anyhow, to make development possible, a community needs to know itself first. That is, the community must analyze its society, and the important tool that can be efficiently used is Participatory Rural Appraisal (PRA) the emphasis of which is for the local people to learn in order to comprehend the reality of the community themselves, which is a part of the participatory practical research process. However, the application of this tool in a community requires external factors, which may necessitate the researcher for development to become a change agent. Therefore, he has to learn, explore, research and analyze along with the community members. Thus, the theoretical framework for the co-working and co-living of a researcher and a community is phenomenology, which will make the researcher become a part of the community. From a point of view of researchers, this method is called participatory action research. The community will be the researchers as well as the target of the research at the same time. As the community attains self-awareness, the aim of community change is 
sustainable development, which is the major vision for the community to attain. In development, the cognition of mechanisms of social change is needed. In bringing change to the Phu Kratae Island community, the researcher saw the mechanisms of ideology, economy, technology, as well as cooperation, for example, community business in the form of tourism based and centered on the community. The role of the researcher was to induce appropriate change and to use the appropriate strategies in inducing change. Therefore, persuasive strategies in combination with re-educative strategies and facilitative strategies were employed as the major strategies, which means examining the mechanisms of social change. After successfully applying the right strategies, Phu Kratae community will be able to use community-based tourism as a mechanism of change towards sustainable development.

The next step was thus the search for tools and techniques for developing the community towards sustainability. This process of study eventually led to the research framework. Therefore, this stage of the study consisted of communitybased tourism, eco-tourism and sustainable tourism [6], entrepreneurship and marketing development processes [7, 8], method of evaluation for decisionmaking and management model [9], participatory action research with AIC and PRA techniques as tools in developing community-based tourism [10] and community business [11].

\begin{tabular}{|c|c|}
\hline $\begin{array}{l}\text { Phu Kratae Island } \\
\text { Community }\end{array}$ & $\begin{array}{l}\text { Changes in the Community after } \\
\text { Community-Based Tourism Business }\end{array}$ \\
\hline$\downarrow$ & * level of potential for an eco-tourism \\
\hline $\begin{array}{l}\text { Participatory } \\
\text { Action Research } \\
\text { (PAR) and AIC \& } \\
\text { PRA techniques }\end{array}$ & $\begin{array}{l}\text { * level of potential for management and } \\
\text { service } \\
* \text { level of tourists' satisfaction with service } \\
\text { and tourism resources }\end{array}$ \\
\hline $\begin{array}{l}\text { Sustainable } \\
\text { Tourism }\end{array}$ & operation \\
\hline
\end{tabular}

Figure 1: $\quad$ Research conceptual framework.

\section{Research hypothesis}

There is difference in the potential of the Phu Kratae Island Tourism Club committee for management and service after education. 


\section{Research methodology}

\subsection{Objective 1}

The research was conducted by assessing the potential of the ecological system of Phu Kratae Island for being developed into a new tourism location, assessing the potential of the community members for being developed into tourism entrepreneurs, examining the potential of the Phu Kratae Island Tourism Club for management and service and developing the efficiency the Phu Kratae Island Tourism Club committee for tourism activity operation, recreation area management and business management.

\subsection{Population and sampling procedure}

The respondents of this research were (1) 60 Phu Kratae Island community members and 15 senior community members, obtained through purposive sampling, (2) 30 members of the Phu Kratae Island Tourism Club committee, obtained through no random sampling.

Furthermore, the indexes for determining the potential of the community members for being developed into entrepreneurs are (1) the community members' knowledge about tourism resources of the community, (2) their readiness for tourism business management by the community, (3) their participation in the operation of community tourism activities and (4) availability of organizations or community groups for tourism management by the community.

\subsection{Research instruments}

In this research, the methods of data gathering are participatory inquiry, interview, conversation and observation among the researcher, scholars and the Phu Kratae Island community, that is, thinking and interactive learning through intensive actions. Every party had to cooperate on the foundation of love and compassion with no enmity [12].

\subsection{Pre-testing of the instruments}

The data for this stage of the research are qualitative, and so required examination of data matching as well as that of the researcher's interpretation regarding different layers of reality and the respondents' views. This is performed through triangulation which involves examining sources of data, that is, data triangulation and methodological triangulation. All the data used in the research and interpretation must be inspected periodically by the concerned party at every stage. 


\subsection{Data gathering methods}

Three methods of data collection were used in this research: A. data collection through related documents; B. data collection through observation, which means keeping an eye on or studying the matter minutely in order to acquire the intended information and $\mathrm{C}$. data collection through interview and observation. The researcher used interview as a data-collecting instrument along with observation. In a qualitative research, "human" is an instrument for data collection. The researcher used interview with the respondents from the collection of factual data to that of subjective data.

\subsection{Data analysis}

The researcher analyzed the data collected from the interview form by content analysis. In addition, the potential of the club committee for management and service refers to the capability of area / recreation administration, business management, as well as the club committee's service. The potential was evaluated through the assessment of the levels of knowledge and attitudes regarding the operation of tourism activities before and after the procedure of educating the club committee with the use of a knowledge survey form and an attitude survey form. Regarding this matter, the club committee with potential for management and service must have higher levels of knowledge and attitudes after the education. The assessment was done with the paired t-test [13].

\subsection{Objective 2}

The research was conducted by performing community service to tourists who came repeatedly for about 10 months and collecting data on views and satisfaction of tourists with the use of an opinion and satisfaction survey form. The respondents in this research consist of the first group of tourists of about 68 in number and the second group of about 110,178 tourists in total, with no random sampling.

\subsection{Objective 3}

The research was conducted by collecting data on views and recommendations from Phu Kratae community members by using the survey form on the perception of the results of conducting the project's tourism activities. The respondents in this research comprise 306 Phu Kratae community members, sampled by stratified random sampling.

\subsection{Research duration}

This research took about 20 months, starting from September 2007 to June 2009. 


\section{Results and discussion}

1) The tourism location of Phu Kratae Island passes the standard of area potential by the criteria of the Office of Tourism Development. This certifies that the island can be an eco-tourism location in case there has been no administration. Furthermore, the club committee has potential for management and service. They want to operate the tourism business of the community and they can be formed into a tourism club of the community. As seen after the educative process, the potential of the club committee for management and service was better than before the process, as assessed by the t-test (knowledge level: $\mathrm{t}=-7.79^{* * *}, \mathrm{p}=0.001$ and attitude level: $\mathrm{t}=-10.34 * * *, \mathrm{p}=0.001$ (which confirms the research hypothesis).

2) During the first period of the assessment, the tourists had a low level of dissatisfaction with the over all service, but they had a low level of satisfaction with guides, service charges, as well as the orderliness of the community. Then during the period of assessing advance, the tourists still had a low level of satisfaction with the over all service, but the condition was better than during the first period.

3) The community members thought that the tourism activities yielded better results to the economic, society, and cultural conditions, as well as lifestyle and environment. That is, this project provided the villagers with more income and more earning opportunity. The rapport in the community is better. The assemblage and cooperation in the community are better. The villagers are proud of their identity as well as their tradition and culture. They are also proud of the value of their culture. This project brought the villagers closer to nature, and the cooperation and participation in the conservation and protection of natural resources have also increased. This reflects the improved conscience of valuing the environment and nature. From the results of the research on community-based tourism business development, it was found that the Phu Kratae Island community made positive changes towards sustainable tourism. The results can be discussed as follow:

3a) The potential for being an eco-tourism location of the Phu Kratae Island community passed the standard of the Office of Tourism Development, which means this area can be developed into an eco-tourism location of a rather good level, in case there has never been any tourism management of this location before. On tourism resources, they are still attractive. Regarding this matter, Silanoi [14] mentioned that the development of a community tourism location requires planning, and the first thing to do is site evaluation, to see the existing conditions and consider what to be added. However, after a period of tourism management by the community, the tourism location should be re-evaluated to see if the changes are according to the set goal, which is sustainable tourism. Moreover, the potential of the area also corresponds with Suwan's concept of tourism potential [15] that it is the physical carrying capacity of an area, that is, the suitability of the physical condition of a tourism location for being developed into a tourism location as intended and the tourism location's ecological capacity 
- the ecological carrying capacity of the natural environment inside and around the area for the development of the area into an educational tourism location.

3b) However, the Office of Tourism Development [16] explained that the potential for being an eco-tourism location is the most important factor. The eco-tourism location should be a natural site from which pleasure can be attained in learning and coming into contact with the ecological system. This is probably related to the local culture and thus allows tourists to learn about a culture with natural lifestyle or being part of the ecological system of that tourism location. In addition, consideration of tourists' safety is an important factor in managing eco-tourism in a natural site. As for the case of the Phu Kratae Island tourism location, the consideration of this factor displays that it is rather outstanding in the index identifying a natural location with tourism and learning attraction rather than other indexes, since the evaluation results yield that most of the concerned individuals mentioned that for the Phu Kratae Island tourism location, these appeal factors can attract tourists in the region and the island is considered a novel kind of tourism location in the Isaan region, the most part of which is plateau, for Phu Kratae Island is amid the water, an interesting thing and a tourism location hard to find in this region.

3c) The above results correspond to the total conceptual framework (sustainable tourism) in the following points: (1) Effects on the environment, whether natural or social and cultural ones must not exist, or if they do, it must be in the lowest degree. (2) The management is sustainable, covering resource preservation, environmental governance, pollution prevention and removal and the tourism development must be controlled in scope. (3) Lastly, the tourism must benefit the local community and return the benefits to the local tourism resources and environment because the local community has the most significant role in bearing the consequences of tourism by the community. Also, to a certain degree, the results can be compared with the set goal, that is, sustainable tourism in terms of the economy, society, culture, lifestyle and environment of the community, which is a goal in line with the concept of Sarobon [17] that there exist a various great number of goals of management by the community, of the community and for the community. One is community environmental management. This goal corresponds with the concept of sustainable tourism development, which is the cooperation of the community as a whole in considering the physical carrying capacity and the capacity of the community for organizing activities for tourists, and the idea of Pocharee [18] that the application of the participatory procedure in community-based tourism management can be a significant instrument in processing a participatory tourism activity on the foundation of local wisdom, which yields a learning process, love and cherishment for the local area as well as inducing sustainable tourism development.

\section{Conclusions and recommendations}

From the research on the development of tourism business based on Phu Kratae community, there are suggestions for individuals concerning tourism activity- 
processing and those who may use the results as guideline for more profound investigation as follow:

\section{Chairperson and committee of Phu Kratae Island tourism club:}

1) Make a plan for meeting with the club members every month, scheduling the free time when all the club members can join the meeting to share information on the club's tourism management, as well as discussing and making decisions concerning the fair benefits of the members.

2) Have the club committee and members study and collect important historical and cultural information of the community as well as natural diversity in the conserved forest and surrounding area and collaborate with the head and teaching staff of the tourism department of Ubonratchathani University in organizing a community database to be publicized.

3) Organize a project soliciting assistance from the head and teaching staff of the tourism department of Ubonratchathani University to conduct training projects for the members and villagers who are interested in tourism administration by the community in these matters: (1) keeping club accounts efficiently, (2) setting marketing strategies for the club, (3) becoming a local guide with potential for communication with tourists, (4) providing lodgings and vehicles to accommodate tourists, (5) performing various native arts to welcome tourists and (6) techniques of rendering good-quality service for increase of knowledge, skills and expertise.

4) Make projects publicizing the community's tour projects to the community members through a news distribution station or community ceremonies. Also providing interesting information about the tourism location and tour program lists in the community tourism information center as well as residences of members and villagers. Assigning the club committee the task of operation for continual and consistence communication with the community.

5) Have the club committee and members improve the service standard of the members in (1) homestay lodging. The bathroom facilities should always be clean and the bedding be in keeping with the standard of the Office of Tourism Development, Ministry of Tourism and Sports. (2) For the tour vehicle (wheel ploughs), the seats should be well-fastened and made safe, equipped with handles to assist getting in and out of the vehicles for convenience and confidence in the service.

Chairperson and staff of the Sub-District Administrative Office of Nonklang, Phiboonmangsaharn district, Ubonratchathani province:

6) Include the community tourism project into the year plan of the SubDistrict Administrative Office of Nonklang in order to request a budget in support of the promotion of tourism by the community, setting it as a development project of Nonklang to be publicized to other communities.

7) Organize annual projects in support of the special marketing of the SubDistrict Administrative Office of Nonklang, assigning the responsible staff to issue certificates as well as prizes for supporting the sub-district's tourism to be given to the Phu Kratae community - village headman, village committee, as 
well as villagers to be an example for other communities and to publicize the sub-district's tourism.

8) Organize a project in search of supporters for activities in tourism by the community of the Sub-District Administrative Office of Nonklang to present to the Administrative Office of Ubonratchathani province, Phiboonmangsaharn municipality. Find business entrepreneurs, companies and shops in the area for financial support for supplying equipment used in the activities of Phu Kratae community that have not been carried out according to the club's plan, such as tourists' camping tents, fishing equipment, tour bikes and apparatus for producing souvenirs bearing the identity of the local area to sell to tourists.

Director of the Tourism Authority of Thailand, area 2, Ubon Ratchathani:

9) Include Phu Kratae community tourism in the list of the office tour advertisement for public relations.

10) Include Phu Kratae community tourism in the office's development plan and support the Phu Kratae Tourism Club in efficient education of tourism techniques within the community, methods of finding tourist market for tourism by the community and investment in providing facilities for tourism in Phu Kratae Island community.

11) Organize activities to publicize the project of tourism by Phu Kratae community to the public through the office's media channels, such as brochures, websites, presentation to the public to publicize the office's tourism, as well as offering opportunity to delegates of local tourism companies to try the club's services as another form of publicizing.

Head and teaching staff of the Tourism Department, Ubonratchathani University:

12) Hold an orientation for educating and training skills as well as regularly sharing experience about tourism and tourism management for the members of Phu Kratae Island Tourism Club.

13) Form a program for training skills lacking in the club members for the club, such as providing nature interpretation, tourism management, project planning and evaluation, tourism marketing, and public relations.

14) Cooperate with the club to research and promote development with a goal to increase tourism spots and tourism activities by the community, especially activities that directly pertain to education and environment preservation.

\section{References}

[1] Seesang, P., Personal Communication,13 December 2006, Chairman of the Sub-District Administrative Office of Nonklang, Ubonratchathani Thailand.

[2] Taylor, D., and Stanley, D, Tourism, sustainable development and the environment: an agenda for research. Journal of Travel Research, 31(1), pp. 12, 1987. 
[3] Hans, G. and Mills, C., Character and Social Structure. Brace and World New York, 1953.

[4] Smelser, J., Sociology, 3rd ed., Prentice Hall: Englewood Cliffs, 1988.

[5] Vago, S, Social Change, Holt, Rinehart and Winston: USA, 1980.

[6] Shirley, E., Beyond the Green Horizon: Principles for Sustainable Tourism, World Wide Fund for Nature: Surrey, UK, 1992.

[7] Fennell, D. A. Ecotourism : An Introduction. Routledge: London, 1999.

[8] Dowling, R. K. Ecotourism in Southeast Asia: a golden opportunity for local communities. Tourism in Southeast Asia: A New Direction, Haworth Hospitality Press: New York, pp. 1-20, 2000.

[9] Tanupon. Numchai, Agricultural Promotion Planning and Evaluation, $2^{\text {nd }}$ ed., Maejo Institution of Agriculture: Chiangmai, 1989.

[10] Sumayao, B.R., Participatory Action Research. Faculty of Agricultural Business, Maejo University: Chiangmai, 1999.

[11] Kaewtep, K., Community Culture Work Tools, Catholic Council of Thailand for Development: Bangkok, 1995.

[12] Research and Development Institute, Khon Kaen University, Community Organizations, Mechanism for Solving Social Problems and Social Development, Thailand Research Fund: Bangkok, 1997.

[13] Field, A., Discovering Statistics Using SPSS for Windows. London: Sage Publications. 2000.

[14] Silanoi, L., Development of community tourism locations. E-TAT Tourism Journal, 17(2), pp. 16, 2007.

[15] Suwan, M., Ecology and Economical Development, $2^{\text {nd }}$ ed., Odean Store Press: Bangkok, 1995.

[16] Office of Tourism Development, The Project of Investigation and Determination of Eco-Tourism Site Quality Standard Indicators (complete research), Office of Tourism Development, Ministry of Tourism and Sports: Bangkok, 2005.

[17] Sarobon, S., Sustainable tourism community: recommendations for the adjustment of an excellent Thai tourism community. E-TAT Tourism Journal, 19(6), pp. 19, 2007.

[18] Pocharee, L., Northeastern Local Wisdom Based Participatory Management of Agricultural Tourism Activities, doctoral thesis, Mahasarakham University: Mahasarakham, 2007. 